\title{
Binge Eating Disorder in Patients with Type 2 Diabetes: Diagnostic and Management Challenges
}

This article was published in the following Dove Press journal:

Diabetes, Metabolic Syndrome and Obesity: Targets and Therapy

Jonathan D Chevinsky'

Thomas A Wadden ${ }^{2}$

Ariana M Chao $\mathbb{I D}^{2,3}$

'SUNY Downstate Health Sciences University, Brooklyn, NY, USA; ${ }^{2}$ Perelman School of Medicine at the University of Pennsylvania, Department of Psychiatry, Philadelphia, PA, USA; ${ }^{3}$ University of Pennsylvania School of Nursing, Department of Biobehavioral Health Sciences, Philadelphia, PA, USA
Correspondence: Ariana M Chao University of Pennsylvania School of Nursing, 4I8 Curie Blvd, Philadelphia, PA 19104, USA

Tel $+|2| 5-746-7 \mid 83$

Fax +1215-898-2878

Email arichao@upenn.edu
Abstract: Type 2 diabetes mellitus (T2DM) is associated with an increased risk of disordered eating behaviors including binge eating disorder (BED). Comorbid BED in patients with T2DM has been associated with adverse clinical outcomes such as higher body mass index (BMI) and depressive symptoms. Identifying and addressing this disorder in patients with T2DM is a significant challenge for health-care providers. The purpose of this narrative review is to discuss current perspectives on BED in the context of T2DM with implications for screening and management of these highly comorbid conditions. BED continues to be underrecognized and underdiagnosed. However, there are established tools that providers can use to screen for BED such as the SCOFF Questionnaire and Questionnaire on Eating and Weight Patterns-5. There are several effective treatments for BED including cognitive behavioral therapy, interpersonal therapy, and lisdexamfetamine dimesylate. However, few studies have examined the effects of these treatments in patients with co-morbid T2DM and BED.

Keywords: binge eating disorder, eating disorders, diabetes, obesity

\section{Background}

Over 30 million Americans suffer from type 2 diabetes mellitus (T2DM), comprising the seventh leading cause of death in the United States. ${ }^{1}$ Some of the most common comorbid medical conditions with T2DM include overweight and obesity, sleep apnea, cardiovascular disease, kidney disease, hypertension and hyperlipidemia. ${ }^{2-5} \mathrm{~T} 2 \mathrm{DM}$ is also associated with increased risks of psychiatric conditions such as depression and binge eating disorder (BED). ${ }^{6-8}$

BED was first added to the Diagnostic and Statistical Manual of Mental Disorders (DSM) in 1994 as a feature of eating disorder not otherwise specified (EDNOS), and did not gain formal recognition as its own psychiatric condition until 2013 in the DSM-5. To meet criteria for BED, patients must display recurrent episodes of binge eating, defined as the consumption of an objectively large amount of food, with a sense of loss of control over eating. Such eating must occur on average once per week for the previous 3 months. The episodes must cause marked distress and occur in the absence of compensatory behaviors (e.g., self-induced vomiting, laxative misuse). In addition, patients must have three of five associated features; i.e., eating more rapidly than normal; eating until uncomfortably full; eating large amounts of food when not physically hungry; eating alone because of embarrassment; or feeling disgusted with oneself, depressed, or very guilty after overeating. Based on the frequency of binge eating episodes, the 
severity of the disorder can be classified as mild (1-3 episodes/week), moderate (4-7 episodes/week), severe (8-13 episodes/week) and extreme (>14 episodes/week). These criteria largely accord with the World Health Organization's ICD-11 classification of BED, with the ICD-11 defining binge eating as when an individual feels a loss of control and the individual eats notably more or differently than usual and feels unable to stop eating or limit the type or amount of food eaten. ${ }^{9}$

BED is the most common eating disorder in the world, with a lifetime prevalence of $1.4 \% .{ }^{10}$ One recent systematic literature review found the point prevalence average (and range) to be $2.3 \%(0-9.8 \%)$ in women and $0.3 \%(0-0.5 \%)$ in men. ${ }^{11}$ There is wide variability in prevalence across countries. For example, a meta-analysis of studies from Latin American showed a mean point-prevalence of 3.5\% for BED. ${ }^{12}$ In addition to T2DM, BED is also associated with a number of psychiatric and metabolic conditions including mood disorders, substance use disorders, overweight and obesity, and dyslipidemia ${ }^{13-16}$ as well as impaired health-related quality of life and increased healthcare costs. ${ }^{17} \mathrm{BED}$ and T2DM each present a number of diagnostic and management obstacles that complicate care of patients with both of these conditions.

\section{Prevalence}

Many, ${ }^{7,8,18-20}$ but not all, ${ }^{21,22}$ studies have reported a greater prevalence of BED in patients with T2DM than those without T2DM. Prevalence rates in patients with T2DM have ranged widely from a point prevalence of 1.4 to $25 \%{ }^{7,8,19,23,24}$ Some studies however, like that by Kenardy et al, ${ }^{22}$ noted an association between T2DM and some degree of binge eating, but not BED itself. These conflicting results may be due to differences in exclusionary criteria, sample characteristics, and the setting in which participants were recruited. For example, patients may have been excluded if they were on anti-depressants or anti-psychotics or if they had substance or alcohol dependence. Rates of comorbidity may also vary in clinical vs community settings. In addition, conflicting results may be related to the threshold shifts for BED that occurred during different revisions of the DSM. Most notably, the DSM-IV-TR requires binge eating to occur at least 2 days a week for 6 months, whereas the DSM- 5 requires binge eating only 1 day a week for 3 months. ${ }^{25}$ This lower threshold for diagnosis has resulted in modestly higher BED lifetime prevalence estimates in the US population $(1.52 \%$ for DSM-IV-TR and $2.03 \%$ for DSM-5). ${ }^{26}$
Conversely, BED has also been shown to be a risk factor in the development of T2DM. In a meta-analysis of cross-sectional studies, Nieto-Martínez et $\mathrm{al}^{27}$ found that relative to those without BED, those with BED had an increased risk of $\mathrm{T} 2 \mathrm{DM}(\mathrm{OR}=3.7,95 \% \mathrm{CI}=1.1,12.1)$. However, cohort studies have shown a non-significant relationship $(\mathrm{OR}=3.3,955 \mathrm{CI}=0.9,13.1)$. It is likely that the varying methods used for diagnosing BED, as well as the inclusion of patients with insulin dependent diabetes mellitus, may have resulted in this discrepancy. Moreover, lifetime prevalence of T2DM in BED patients has been shown to be as high as one in three, with one study showing that the eating disorder predates $\mathrm{T} 2 \mathrm{DM}$ in $90 \%$ of patients with these two comorbid conditions. ${ }^{28,29}$

\section{Dietary Considerations}

One important complicating factor in BED that presents a challenge to T2DM management is the dietary choices that are frequently made by patients with BED. During binge eating episodes, some studies have shown that patients with BED consume a disproportionately high percentage of their calories from fat, ${ }^{30-32}$ as well as carbohydrates. ${ }^{33}$ Others have suggested similar macronutrient compositions despite increased caloric intake. ${ }^{34,35}$ Studies evaluating the specific types of food most common in binges have generally shown high rates of high-carbohydrate foods like sweets, breads and pasta. ${ }^{34,36}$ Newer research by Goodman et $\mathrm{al}^{37}$ has validated this idea by showing that individuals with a greater preference for sweeter foods had an increased binge eating frequency. This suggests that dietary interventions may need to be more extensive in patients with T2DM and BED.

\section{Medical Concerns}

BED complicates the care of people with T2DM in a number of physical and psychological ways that make screening and treatment of BED of the utmost importance. Perhaps the most concerning issue in this regard is the effect that binge eating has on glycemic control. While this likely plays a role in BED leading to T2DM, it certainly complicates its care as well. Perhaps the most foundational study in this regard is that of Parry et $\mathrm{al}^{38}$ which studied the effect of a single day of a high-fat, high-calorie diet on insulin sensitivity. This study of 15 healthy adults found that overall insulin sensitivity decreased by $28 \%$ in these individuals, compared to their non-overeating baseline level. This study suggests that each individual binge may contribute to loss of insulin sensitivity. 
While the prior study was largely focused on establishing a link between bingeing and insulin insensitivity, Kenardy et $\mathrm{al}^{39}$ studied 215 patients with T2DM to determine the extent of binge eating prevalent in the group, as well as the impact that binge eating had on glycemic control. This study found that binge eating frequency was positively correlated with poor blood glucose control (assessed by HbAlc) after adjusting for other variables (BMI, exercise level). Moreover, studies have found that compared to patients without binge eating episodes, those who experience binge eating episodes were significantly younger at age of T2DM diagnosis. ${ }^{32,39}$ Younger age of T2DM diagnosis increases the risk for negative cardiovascular and mortality outcomes ${ }^{40}$ thus younger age of T2DM diagnosis among those with BED warrants urgent screening in the BED population for T2DM and early intervention in BED treatment.

The literature suggests that patients with T2DM and BED do not have a significant difference in $\mathrm{HbA} 1 \mathrm{c}$ levels compared to T2DM patients without BED. ${ }^{24,41}$ Çelik et al $^{42}$ found in a study of 152 patients with T2DM that while rates of depression (assessed by the Beck Depression Scale) and disordered eating attitudes (assessed by the EAT) were significantly higher in T2DM patients with comorbid BED, HbA1c levels were similar. The aforementioned Kenardy et al study, which found a correlation between binge frequency and HbA1c levels in T2DM patients, did not find any correlation between $\mathrm{HbAlc}$ and categorical BED diagnosis - possibly due to the small number of participants who met thresholds for BED $(n=45)$. Abraham et $\mathrm{al}^{15}$ screened 3551 subjects from the Framingham Heart Study for objective binge eating (OBE) and found that among those with OBE, the fasting blood glucose was $7.2 \mathrm{mg} / \mathrm{dl}$ higher than those without OBE, and rates of insulin resistance and metabolic syndrome were higher as well. Papelbaum et $\mathrm{al}^{43}$ found that while eating disorders (mostly BED) predicted glycemic control outcomes in patients with $\mathrm{T} 2 \mathrm{DM}$ - both in terms of fasting blood glucose and $\mathrm{HbA1c}$ - this impact was lost once BMI was controlled for. This evidence suggests that while BED as an isolated variable does not have a direct impact on $\mathrm{HbA1c}$ levels, the earlier age of T2DM diagnosis and possible effects of BED on weight status have the potential for worse outcomes. However, further studies are needed to clarify these relationships.

\section{Metabolic Considerations}

The effect of BED on components of metabolic syndrome has been extensively demonstrated in the literature. Hudson et $\mathrm{al}^{13}$ conducted a longitudinal study comparing 134 individuals with BED to 134 age-, sex-, and BMI-matched controls without BED. This study found BED to be independently associated with dyslipidemia, any component of the metabolic syndrome, and $\geq$ any 2 components of the metabolic syndrome. Nagata et $\mathrm{al}^{44}$ conducted a 7 -year follow-up study on longitudinal cohort data from over 5000 young adults with baseline obesity/overweight. Of this sample, $23 \%$ reported disordered eating behaviors (including binge eating); when controlled for BMI, among other demographic characteristics, this study found disordered eating behaviors were associated with elevated rates of incident hyperlipidemia in male patients and greater increase in BMI in all patients. Further studies have served to reinforce this relationship between obesity and BED as a factor affecting potential treatment of T2DM in these patients. ${ }^{24,41,45}$ Finally, a recent study of cytokines and growth factors, and their interaction with obesity and $\mathrm{BED}$, suggests that there are a group of immune mediators that vary between individuals with obesity with or without BED. ${ }^{46}$ This suggests that there is likely an immune component to the metabolic implications of BED that is still not well understood.

\section{Screening and Diagnosis}

There are a number of challenges that affect the screening and diagnosis of BED and its ultimate treatment. While research into the treatment of BED has advanced in recent years, fewer than half of persons with lifetime BED receive treatment. ${ }^{10}$ One factor that contributes to this gap is a lack of familiarity with BED among health-care providers. ${ }^{47}$ Fewer than half of health-care providers report using DSM criteria to diagnose BED, $27 \%$ do not recognize BED as a discrete eating disorder, and over $40 \%$ never assess binge eating at all. ${ }^{48,49}$ Some health-care providers fail to address mental health at all despite one study finding that individuals with BED who are asked about their mental health by their general practitioner are much more likely to see a mental health specialist. ${ }^{50}$ In addition, patients are often reluctant to disclose binge eating symptoms because of feelings of guilt and concerns of provider judgment. ${ }^{51-53}$ This may be related to some patients' lack of readiness to endorse a "loss of control" out of concern of being deemed to lack willpower. ${ }^{54,55}$ Even in circumstances in which patients are comfortable disclosing such information, determining whether a binge quantity is sufficiently large to meet DSM criteria can be challenging, even for clinicians with extensive experience treating BED. Moreover, one systematic review found that individuals 
suffering from eating disorders are much more likely to seek treatment for their weight than they are for their eating disorder, with this phenomenon being most pronounced in BED. $^{56}$ The body of literature surrounding the specific screening tools for BED in patients with $\mathrm{T} 2 \mathrm{DM}$ is quite limited. However, there are effective screening and diagnostic tools, which can be used to identify patients with BED, that have been tested in other patient populations. While this review focuses exclusively on studies conducted in English, it is of note that the following tools have been translated into numerous languages including: Arabic, ${ }^{57,58}$ Chinese, ${ }^{59-61}$ Fijian, ${ }^{62}$ Finnish, ${ }^{63,64}$ French, ${ }^{65,66}$ German, ${ }^{67}$ Greek, ${ }^{68}$ Italian, ${ }^{69}$ Lithuanian, ${ }^{70}$ Malay, ${ }^{71}$ Portuguese, ${ }^{72}$ Spanish, ${ }^{73-76}$ and Turkish. ${ }^{77,78}$

\section{Brief Screening SCOFF}

Researchers have created BED screening tools that are brief, with the aim of increasing rates of use. The SCOFF questionnaire, named as an acronym for the 5 questions that comprise it (Table 1), is a simple, intuitive screening tool created in 1999 by Morgan et al $^{79}$ to screen primarily for $\mathrm{AN}$ and BN in young women. The SCOFF questionnaire has been widely validated for $\mathrm{AN}$ and $\mathrm{BN}$ using a cutoff value of $\geq 2$ positive responses, ${ }^{65,80-82}$ though the data regarding its use in BED is still largely nascent.

\section{Eating Disorder Screen for Primary Care}

Cotton et al $^{83}$ created a five question survey (amended to a four question survey shortly thereafter) in 2003 called the Eating Disorder Screen for Primary Care (ESP) (Table 1). The foundational study that supported the survey tracked $\mathrm{BED}$ diagnosis, as well as $\mathrm{AN}$ and $\mathrm{BN}$, among 233 total screened patients. This study found that using a cutoff of 2 , the SCOFF had a sensitivity and specificity of $78 \%$ and $88 \%$, compared to $100 \%$ and $71 \%$ for the ESP, for all eating disorders tracked.

\section{Screen for Disordered Eating}

Recently, Maguen et al ${ }^{84}$ created the Screen for Disordered Eating (SDE) and compared the validity of this screening tool to the SCOFF and ESP in a sample of 407 female veterans, with the Eating Disorder ExaminationQuestionnaire (EDE-Q) used as the gold standard measurement (Table 1). For BED in particular, this study found that while the ESP was the most sensitive of these screeners $(100 \%)$ and the SCOFF was the most specific $(78.2 \%)$, the SDE represented a reasonable balance between these two factors (sensitivity of $87.2 \%$, specificity of $54.9 \%$ ) when all used a cutoff value of two positive responses. While there is no gold standard for brief screening tools for BED, benefits of the three listed surveys are that they are simple to remember and easy to administer and score. Several options are available for longer screening measures, which can be more cumbersome for the patient and clinician, but may be considered if patients are high risk.

\section{Extensive Screening Binge Eating Scale}

The Binge Eating Scale (BES) is one of the most widely used and tested questionnaires for binge eating behaviors. However, this questionnaire does not map onto the DSM criteria for binge eating disorder. First created in the early 1980 s by Gormally et al $^{85}$ this sixteen question survey has been extensively validated in numerous patient populations, ranging from those with obesity and overweight ${ }^{86}$ to adolescents ${ }^{87}$ to bariatric surgery candidates. ${ }^{88-90}$ Duarte et $\mathrm{al}^{91}$ used the BES in a sample of 1008 female college students and found the sensitivity and specificity to be $81.8 \%$ and $97.8 \%$ respectively, with $96.7 \%$ of patients correctly classified when using a cutoff score of $\geq 17$. While this also helps validate this questionnaire, the importance of extremely high sensitivities in screening tests means that this perhaps still leaves something to be desired.

\section{Eating Disorder Examination Questionnaire}

The Eating Disorder Examination Questionnaire (EDE-Q) is a survey adapted from the Eating Disorder Examination (EDE), a structured interview that has been studied in BED and several other eating disorders. The EDE was created by Cooper and Fairburn ${ }^{92}$ in 1987, adapted into questionnaire form for screening purposes in $1994,{ }^{93}$ and is currently in its seventeenth edition. ${ }^{94}$ The interview and questionnaire both assess the frequency of eating disorder behaviors (e.g., binge eating, self-induced vomiting), as well as the severity of eating disorder psychopathology (i.e., dietary restraint, eating concern, shape concern, and weight concern). The 28-item questionnaire has been shown to have a very high discriminant validity ${ }^{95,96}$ and has been found to be reliable. ${ }^{97}$ Other even shorter versions of the EDE-Q have also been proposed and have proven to be valid alternatives. ${ }^{98,99}$ Furthermore, the majority of studies which have evaluated the concordance of EDE-Q and the much more widely accepted EDE have 
Table I Screening and Diagnostic Tests for BED

\begin{tabular}{|c|c|c|c|}
\hline Questionnaire & Screening Questions & Considerations for Use & Citation \\
\hline \multicolumn{4}{|l|}{ Brief Screens } \\
\hline $\begin{array}{l}\text { SCOFF } \\
\text { questionnaire }\end{array}$ & $\begin{array}{l}\text { Do you make yourself Sick because you feel uncomfortably full? } \\
\text { Do you worry you have lost Control over how much you eat? } \\
\text { Have you recently lost more than One stone in a } 3 \text { month period? } \\
\text { Do you believe yourself to be Fat when others say you are too thin? } \\
\text { Would you say that Food dominates your life? }\end{array}$ & $\begin{array}{l}\text { Validated using a cutoff value of } \geq 2 \text { positive } \\
\text { responses }\end{array}$ & $\begin{array}{l}\text { Morgan } \\
\text { et } \mathrm{al}^{79}\end{array}$ \\
\hline $\begin{array}{l}\text { Eating Disorder } \\
\text { Screen for Primary } \\
\text { Care (ESP) }\end{array}$ & $\begin{array}{l}\text { Are you satisfied with your eating patterns? } \\
\text { Do you ever eat in secret? } \\
\text { Does your weight affect the way you feel about yourself? } \\
\text { Do you currently suffer with or have you ever suffered in the past with } \\
\text { an eating disorder? }\end{array}$ & $\begin{array}{l}\text { Validated using a cutoff value of } \geq 2 \text { positive } \\
\text { responses }\end{array}$ & $\begin{array}{l}\text { Cotton } \\
\text { et } \mathrm{al}^{83}\end{array}$ \\
\hline $\begin{array}{l}\text { Screen for } \\
\text { Disordered Eating } \\
\text { (SDE) }\end{array}$ & $\begin{array}{l}\text { Do you often feel the desire to eat when you are emotionally upset or } \\
\text { stressed? } \\
\text { Do you often feel that you cannot control what or how much you eat? } \\
\text { Do you sometimes make yourself throw up (vomit) to control your weight? } \\
\text { Are you often preoccupied with a desire to be thinner? } \\
\text { Do you believe yourself to be fat when others say you are thin? }\end{array}$ & $\begin{array}{l}\text { Validated using a cutoff value of } \geq 2 \text { positive } \\
\text { responses }\end{array}$ & $\begin{array}{l}\text { Maguen } \\
\text { et } \mathrm{al}^{84}\end{array}$ \\
\hline \multicolumn{4}{|c|}{ Extensive Screening } \\
\hline $\begin{array}{l}\text { Binge Eating Scale } \\
\text { (BES) }\end{array}$ & $\begin{array}{l}\text { I6 questions, assessing behavioral manifestations and emotional impacts } \\
\text { of binge eating }\end{array}$ & $\begin{array}{l}\text { Created for use with obesity or overweight, }{ }^{86} \text { but } \\
\text { validated in adolescents }{ }^{87} \text { and bariatric surgery } \\
\text { candidates }^{88-90}\end{array}$ & $\begin{array}{l}\text { Gormally } \\
\text { et } \text { al }^{85}\end{array}$ \\
\hline $\begin{array}{l}\text { Eating Disorder } \\
\text { Examination } \\
\text { Questionnaire } \\
(\text { EDE-Q) }\end{array}$ & $\begin{array}{l}28 \text { questions, assessing: restraint, eating concern, shape concern, and } \\
\text { weight concern }\end{array}$ & $\begin{array}{l}\text { Adapted from the frequently used Eating Disorder } \\
\text { Examination (EDE), structured clinical interview }\end{array}$ & $\begin{array}{l}\text { Fairburn } \\
\text { et } \mathrm{al}^{93}\end{array}$ \\
\hline $\begin{array}{l}\text { Questionnaire on } \\
\text { Eating and Weight } \\
\text { Patterns-5 } \\
\text { (QEWP-5) }\end{array}$ & $\begin{array}{l}26 \text { questions, assessing demographic information and disordered eating } \\
\text { behaviors over the last } 3 \text { months }\end{array}$ & $\begin{array}{l}\text { Most studies testing its validity utilized previously } \\
\text { revised version (QEWP-R) }\end{array}$ & $\begin{array}{l}\text { Spitzer } \\
\text { et al }{ }^{105} \\
\text { Yanovski } \\
\text { et al }{ }^{107}\end{array}$ \\
\hline \multicolumn{4}{|l|}{ Diagnostic Tests } \\
\hline $\begin{array}{l}\text { Eating Disorder } \\
\text { Examination (EDE) }\end{array}$ & $\begin{array}{l}\text { Clinician administered version of EDE-Q assessing the primary domains } \\
\text { of: restraint, eating concern, shape concern, and weight concern }\end{array}$ & $\begin{array}{l}\text { Specific to eating disorder diagnosis, assessing } \\
\text { severity and frequency of disordered eating } \\
\text { behaviors over the last month }\end{array}$ & $\begin{array}{l}\text { Cooper } \\
\text { and } \\
\text { Fairburn }\end{array}$ \\
\hline $\begin{array}{l}\text { Structured Clinical } \\
\text { Interview for } \\
\text { DSM-5 (SCID-5) }\end{array}$ & $\begin{array}{l}\text { Clinician administered, systematic evaluation which closely adheres to } \\
\text { DSM-5 diagnostic criteria }\end{array}$ & $\begin{array}{l}\text { General to a wide array of DSM- } 5 \text { disorders, with } \\
\text { one specific domain applicable to eating disorder } \\
\text { pathology }\end{array}$ & $\begin{array}{l}\text { Spitzer } \\
\text { et al }{ }^{116}\end{array}$ \\
\hline
\end{tabular}

shown that binge eating frequency was well-correlated between these two measures. ${ }^{100-103}$

A challenge with self-reported questionnaires is difficulty discriminating an objectively large from a subjectively large amount of food. One approach that has been used to address this challenge is to include more detailed instructions in the EDE-Q. ${ }^{105}$ The instructions include example scenarios to differentiate different types of eating episodes including: objective binge eating episodes (i.e., consumption of an objectively large amount of food and sense of having lost control while eating); objective overeating episodes (i.e., consumption of an objectively large amount of food without a sense of loss of control); subjective binge eating episode (i.e., a sense of loss of control over eating but the amount is not necessarily large). Inclusion of these brief, detailed examples help to improve the performance of the assessment. 


\section{Questionnaire on Eating and Weight Patterns-5}

The Questionnaire on Eating and Weight Patterns (QEWP) was developed in 1992 by Spitzer et al $^{105}$ as part of a larger field trial with the goal of defining BED and determining its prevalence and associated patterns of overeating. In 1993 it was first expanded ${ }^{106}$ and then updated to the revised QEWP-R to align more closely with BED diagnostic criteria. It has been further updated in accordance with the newest DSM-5 diagnostic criteria (QEWP-5). ${ }^{107}$ The QEWP-R has been validated as a reasonable screening option by Borges et $\mathrm{al}^{109}$ in a Brazilian sample of 89 overweight women, with a sensitivity of $55 \%$ and specificity of $80 \%$ in screening for BED and a sensitivity of $88 \%$ and specificity of $63 \%$ in screening for any binge eating. Nangle et $\mathrm{al}^{109}$ used the QEWP in a sample of 52 self-referred binge eaters compared to 52 controls who did not report binge eating and found the QEWP to have a $71.4 \%$ sensitivity and $69.2 \%$ specificity in screening for patients who are high probability bingers ( $>25 \%$ intakes rated as binges).

The above questionnaires have been compared in two studies. Celio et $\mathrm{al}^{110}$ used the formal, clinician administered $\mathrm{EDE}$ as the standard for diagnosis and compared these questionnaires in a sample of 157 adults, 129 of whom had been diagnosed with BED based on the EDE. The QEWP-R and the BES were fairly sensitive ( $74 \%$ vs $85 \%$ ) but highly nonspecific ( $35 \%$ vs $20 \%$ ). The modified, two-item version of the EDE-Q correlated highly with the EDE regarding number of total binge eating days as well as total number of binges. Gladis et al ${ }^{111}$ compared the QEWP and BES in a sample of 128 women with obesity specifically attempting to track binge eating diagnostic concordance among these two screening tools. The BES and QEWP only had a modest overlap (kappa $=0.45$ ), though each study identified a similar number of participants with BED, and subgroup analysis suggested that it was impossible to attribute this discrepancy to errors in either one of these tools. What these studies suggest is that there is no single, uniformly accepted gold standard screening tool for BED. Thus, if BED is suspected in a patient with T2DM, the EDE-Q and QEWP-5 are valid options.

\section{Diagnosis}

The gold standard method for diagnosing BED is to conduct a structured interview for the DSM- 5 criteria performed by a qualified clinician. There are two clinician-administered diagnostic tests which have been used for this purpose, after a patient has screened positive using one of the aforementioned screening tools (Table 1).

\section{Eating Disorder Examination}

The first of these is the Eating Disorder Examination (EDE). This semi-structured clinical interview has been widely validated, including in a study by Wilfley et $\mathrm{al}^{112}$ which found that not only did BED patients score higher than overweight controls on every subscale except restraint, they also had similar scores overall to $\mathrm{AN}$ and $\mathrm{BN}$ patients, for whom this test has been extensively validated. ${ }^{113,114}$ Grilo et $\mathrm{al}^{115}$ demonstrated the reliability of the EDE with BED in identifying the frequency of binges, test-retest reliability, and determining associated eating disorder features.

\section{Structured Clinical Interview for DSM-5}

The Structured Clinical Interview for DSM-5 Disorders (SCID-5) is the most recent in a series of semi-structured clinical interviews for psychiatric disorders beginning in the early 1990s with the Structured Clinical Interview for DSMIII-R. ${ }^{116}$ Since then, it has become widely accepted as a clinician-administered diagnostic test for BED. Published by the American Psychiatric Association (APA), there are four separate versions that can be purchased depending on the specific need - ranging from a version intended for clinicians, to one intended for researchers. The APA estimates that this clinical version should take no longer than 75 minutes to administer. It adheres to the DSM-5 criteria and has a modular format and systematic approach. ${ }^{117}$ While the SCID-5 has not been specifically validated for BED, there is vast evidence supporting the SCID in a wide array of psychiatric conditions. ${ }^{118-121}$

\section{BED Treatment}

Few studies have investigated the treatment of comorbid BED and T2DM. However, several treatments for BED have established efficacy in other populations. Below we review common treatment interventions that have been studied in people with BED including: cognitive behavioral therapy (CBT); interpersonal psychotherapy (IPT); behavioral weight loss (BWL); and pharmacologic treatments (Table 2).

\section{CBT}

CBT is the current treatment of choice for BED given its extensive evaluation and strong empirical support. ${ }^{122,123}$ Therapist-led CBT typically consists of individual or group sessions that occur weekly for 12 to 16 weeks. The goals of CBT for BED are to interrupt binge-eating behavior, learn self-management strategies to establish a more normal eating schedule, change erroneous beliefs 
Table 2 Results from Select Randomized Controlled Trials Comparing BED Treatments

\begin{tabular}{|c|c|c|c|c|c|}
\hline Treatment & Brief Description & Citation & Comparison & Remission of BED & Binge Eating Frequency \\
\hline \multicolumn{6}{|c|}{ Psychological Treatments } \\
\hline $\begin{array}{l}\text { Behavioral weight } \\
\text { loss (BWL) }\end{array}$ & $\begin{array}{l}12 \text { month study of } 80 \text { men } \\
\text { and women with BED }\end{array}$ & $\begin{array}{l}\text { Munsch } \\
\text { et al }{ }^{150}\end{array}$ & CBT & $\begin{array}{l}58 \% \text { remission on } \\
\text { intention to treat } \\
\text { analysis }\end{array}$ & $\begin{array}{l}\text { Decreased from } 14.17 \text { to } 7.54 \\
\text { weekly binges on intention to } \\
\text { treat analysis }\end{array}$ \\
\hline $\begin{array}{l}\text { Cognitive } \\
\text { behavioral } \\
\text { therapy (CBT) }\end{array}$ & $\begin{array}{l}20 \text { week group treatment of } \\
259 \text { patients }\end{array}$ & $\begin{array}{l}\text { Peterson } \\
\text { et } \mathrm{al}^{171}\end{array}$ & $\begin{array}{l}\text { Therapist-led CBT, } \\
\text { therapist-assisted } \\
\text { CBT, self-help and } \\
\text { waiting list }\end{array}$ & $\begin{array}{l}\text { Therapist-led = } \\
51.7 \% ; \text { therapist- } \\
\text { assisted = } 33.3 \% \\
\text { self-help }=17.9 \%\end{array}$ & $\begin{array}{l}\text { Decreased in binge days in } \\
\text { therapist-led ( } 16.0 \text { to } 4.4) \\
\text { therapist-assisted ( } 16.4 \text { to } 7.6) \\
\text { self-help ( } 16.4 \text { to } 9.6)\end{array}$ \\
\hline $\begin{array}{l}\text { Interpersonal } \\
\text { Psychotherapy } \\
\text { (IPT) }\end{array}$ & $\begin{array}{l}2 \text { year study of } 205 \text { women } \\
\text { with BED }\end{array}$ & $\begin{array}{l}\text { Wilson } \\
\text { et al }{ }^{151}\end{array}$ & CBT, BWL & $\begin{array}{l}67 \% \text { remission on } \\
\text { intention to treat } \\
\text { analysis }\end{array}$ & $\begin{array}{l}\text { Decreased from a mean of } 16.1 \\
\text { to } 3.7 \text { days binge eating per } \\
\text { month on intention to treat } \\
\text { analysis }\end{array}$ \\
\hline \multicolumn{6}{|c|}{ Pharmacologic Treatments } \\
\hline Lisdexamfetamine & $\begin{array}{l}\text { Two multicenter, double- } \\
\text { blind, } 12 \text { week trials of } 383 \\
\text { and } 390 \text { adults with BED }\end{array}$ & $\begin{array}{l}\text { McElroy } \\
\text { et al }\end{array}$ & Placebo & $\begin{array}{l}38.2 \% 4 \text { week binge } \\
\text { cessation at week } 12\end{array}$ & $\begin{array}{l}\text { Decreased in least squares } \\
\text { mean of binge eating days/week } \\
\text { by } 3.87\end{array}$ \\
\hline Fluoxetine & $\begin{array}{l}16 \text { week trial of fluoxetine } \\
(60 \mathrm{mg} / \text { day }) \text { compared with } \\
\text { CBT alone and combined } \\
\text { with CBT }\end{array}$ & $\begin{array}{l}\text { Grilo } \\
\text { et al }{ }^{167}\end{array}$ & CBT & $\begin{array}{l}22 \% \text { remission on } \\
\text { intention to treat }\end{array}$ & $\begin{array}{l}\text { Decreased from a mean of } 16.5 \\
\text { to II.0 binge episodes per } \\
\text { month }\end{array}$ \\
\hline
\end{tabular}

about weight and shape, and develop healthier attitudes towards one's body. Participants are taught a variety of skills including identifying triggers of binge eating episodes, correcting beliefs or thought patterns related to binge eating, and altering attitudes regarding food and eating. Skill builders are assigned at each session so participants can practice what they have learned in session. With CBT, $68^{-} 90 \%$ of participants will have a reduction in the number of binge eating episodes, and more than $50 \%$ of participants generally achieve total remission, along with broad improvement in specific eating disorder psychopathology. ${ }^{124,125}$ However, this treatment does not tend to reduce weight. ${ }^{126} \mathrm{CBT}$ is also labor intensive and requires specialist training.

A growing body of research supports the use of guided-self-help (CBTgsh) for mild to moderate severity BED. ${ }^{127,128}$ CBTgsh combines self-help manuals, such as Overcoming Binge Eating by Christopher Fairburn, ${ }^{129}$ with a limited number of brief treatment sessions administered by health-care providers. In one study, CBTgsh had significantly higher remission rates $(46 \%)$ compared to BWLgsh $(18 \%)$ or a control condition $(13 \%) .{ }^{128} \mathrm{An}$ advantage of this treatment is that it may be easier to disseminate while also being cost effective. ${ }^{130}$ However, internet based guided-self-help, while cheaper than in person CBT, has been shown to be less efficacious. ${ }^{131}$

While CBT is not recommended as the primary treatment of T2DM itself, some evidence suggests that it may have a positive short-term effect on glycemic control, though results are inconclusive. ${ }^{132}$ Both therapist-led and guided self-help versions of CBT are well-founded treatments for BED, with fairly strong evidence from metaanalyses and systematic reviews supporting their use. ${ }^{122,126,133}$ Therefore, this treatment should be an early consideration in any treatment plan for BED. However, future studies are needed to test these interventions in patients with co-morbid BED and T2DM.

\section{Interpersonal Psychotherapy}

Other psychological treatments have also been tested for BED including interpersonal psychotherapy (IPT). IPT helps patients identify ${ }^{134}$ and change interpersonal problems that are hypothesized to be maintaining BED. While not as widely utilized as CBT, studies comparing these two options have showed similar short-term and long-term efficacy with BED. ${ }^{135,136}$ However, the largest 
concern with IPT in general is its relative costeffectiveness; while this has not been studied at length in BED specifically, past studies suggest the possibility of increased costs compared to treatment as usual. ${ }^{137}$ Moreover, as a specialty treatment modality it is much less likely to be available as widely as CBT, BWL or any of the pharmacological treatments listed.

\section{Behavioral Weight Loss}

Approximately $15-20 \%$ of participants seeking weight loss have BED. ${ }^{138}$ Behavioral weight loss (BWL) may be an attractive treatment for these individuals since it does not require specialized psychological treatment and may help people manage both their binge eating and weight. In patients with diabetes, BWL can also help improve glycemic control. ${ }^{139-144}$

Concerns have been raised about BED and binge eating being negative prognostic indicators for BWL treatment. While some studies have shown that people with binge eating tend to lose less weight compared to those without binge eating, ${ }^{145,146}$ others have indicated no difference. ${ }^{147,148}$ The Look AHEAD trial compared an intensive lifestyle intervention (ILI) to Diabetes Support and Education (DSE) in patients with T2DM and obesity/ overweight, with a primary goal of evaluating cardiovascular outcomes, while also tracking a number of other biological and behavioral endpoints. ${ }^{149}$ While this study did not find any differences in cardiovascular outcomes, it did observe numerous health benefits of ILI, including reduced need for T2DM medications, greater weight loss, and significantly greater proportion of patients lowering their HbAlc to $<7 \%$ in accordance with ADA glycemic control goals (among numerous other positive metabolic outcomes). Chao et $\mathrm{al}^{145}$ conducted a secondary analysis from the Look AHEAD trial and found that while persistent binge eating attenuated weight loss in patients receiving ILI, those with pre-existing binge eating who stopped binge eating lost a similar amount of weight as those without binge eating at any time. Therefore, ILI is a reasonable recommendation as having efficacy in comorbid BED and T2DM patients in terms of weight loss and improved glycemic control. However, binge eating should be monitored, and those who continue to binge eat may need additional intervention such as CBT.

Another question regarding the treatment of BED has been whether CBT is needed beyond the standard BWL treatment. Relative to BWL, CBT appears to be more effective in reducing binge-eating related psychopathology, but only in the short-term. Munsch et $\mathrm{al}^{150}$ compared CBT and BWL in a sample of patients with BED and found that while shortterm results suggested a faster improvement in binges in the CBT group and a faster BMI reduction in the BWL group, at a 12 month follow up no significant differences remained. In a comparison of 16 weekly sessions of CBT with BWL for patients with BED and obesity, CBT was significantly more effective than BWL in producing remission from binge eating at posttreatment but not at the 12-month follow-up. ${ }^{9}$ In another study, Grilo and colleagues ${ }^{10}$ randomly assigned 125 obese patients with BED to 16 sessions of either group CBT, BWL, or a sequential condition in which CBT was administered first, followed by BWL (CBT + BWL). No significant differences in binge eating remission rates emerged, although CBT produced significantly greater reductions in frequency of binge eating at the 6- and 12-month follow-ups. BWL resulted in a statistically greater percentage reduction in body mass. Wilson et $\mathrm{al}^{151}$ found BWL to be associated with greater 6 month reduction in BMI than CBT, although there were no difference in weight change at 2 year follow-up. There have been efforts to combine BWL and CBT into a single treatment modality called the Healthy APproach to weIght management and Food in Eating Disorders (HAPIFED). ${ }^{152,153}$ However, results are preliminary for this treatment modality, with an early case series of 11 individuals showing high subjective patient-reported suitability and sustainability though inconsistent weight loss or decreased binge frequency. ${ }^{154}$

\section{Pharmacological Treatments for BED Lisdexamfetamine}

Research into effective pharmacologic options for treating BED is limited, though some efforts have been made, in the form of a recent meta-analysis, to compile what little research exists. ${ }^{155}$ The only current Food and Drug Administration (FDA) approved medication for the treatment of BED is the stimulant lisdexamfetamine. While this medication is a mainstay of treatment for attentiondeficit hyperactivity disorder (ADHD), its logical underpinnings as an appetite suppressant and a treatment for a similarly impulsive disorder justified its extensive testing in this population. ${ }^{156}$ Safety and efficacy trials conducted by McElroy et $\mathrm{al}^{157}$ and Hudson et $\mathrm{al}^{158}$ have shown that not only is the safety profile consistent with prior ADHD trials, but that the medication decreased binge eating days, binge-eating related obsessions and compulsions, and more frequently resulted in binge cessation than placebo. While this medication has no specific contraindications for 
use in patients with T2DM, it has known cardiovascular contraindications and must be used with caution in patients with hypertension. Insofar as cardiovascular disease and hypertension may be comorbid in T2DM, this further limits potential treatment options.

\section{Antidepressants}

Second-generation antidepressants are generally superior to placebo in patients with BED. Bupropion-when used in combination with naltrexone-is an FDA-approved weight loss medication which has been shown to have efficacy in inducing weight loss in patients with both T2DM and obesity. ${ }^{159}$ Bupropion on its own, however, has limited effects on reducing binge eating. ${ }^{160}$ A small body of data also supports the use of other second generation antidepressants in BED such as fluoxetine, ${ }^{161}$ fluvoxamine, ${ }^{162}$ citalopram, ${ }^{163}$ and sertraline; ${ }^{164}$ however, as Brownley et al $^{165}$ adeptly point out in their systematic review and meta-analysis, the body of evidence for these medications, while promising, is not sufficient to make clear recommendations. In addition, CBT has been ${ }^{166,167}$ found to be significantly more effective than fluoxetine in producing binge eating remission.

\section{Glucagon-Like Peptide Receptor Agonists}

One final consideration in the realm of anti-obesity or diabetes pharmacotherapy is glucagon-like peptide (GLP)-1 receptor agonists. While these medications are approved for T2DM treatment, liraglutide $3.0 \mathrm{mg}$ /day is also FDA approved for chronic weight loss in patients with a $\mathrm{BMI} \geq 30 \mathrm{~kg} / \mathrm{m}^{2}$ or $\mathrm{BMI} \geq 27 \mathrm{~kg} / \mathrm{m}^{2}$ with a weight-related comorbidity such as T2DM. More than $50 \%$ of patients experience a clinically significant weight loss of $>5 \%$ of body weight after a year of treatment with liraglutide $3.0 \mathrm{mg} /$ day. ${ }^{168}$ Moreover, there is a limited body of research suggesting that in non-diabetic patients with BED, it may improve binge eating while also resulting in weight loss. ${ }^{169}$ Therefore, in comorbid BED and T2DM patients who are already receiving metformin for T2DM and who require dual pharmacotherapy, liraglutide may be an early consideration. Finally, while there has limited research into other GLP-1 agonists like exenatide or lixisenatide, this is an important avenue for future research.

\section{Other Pharmacological Targets}

Anticonvulsants have also been investigated for BED treatment, with topiramate being the most studied of these medications. While further investigation into various medications of this class are required, topiramate has been shown to be linked with weight loss and decreased binge frequency. ${ }^{170}$ Additionally, while metformin is a first-line treatment for T2DM and has been used to induce weight loss, it has never been tested as a treatment for BED. Therefore, this would be a worthwhile target of future study in patients with comorbid BED and T2DM.

\section{Challenges and Future Directions}

The comorbid diagnosis of BED in a patient with T2DM complicates the course of treatment, though research into the implications of this relationship is still limited. The current body of research suggests that not only is BED screening and diagnosis a challenge to clinicians, but management is also a difficult balancing act of weighing the relative evidence of interventions. Metabolic and dietary concerns further complicate care. The best evidence suggests that health-care providers should familiarize themselves with at least one of the brief screening tools mentioned above, with progression to a more elaborate screening tool as warranted or referral to a mental health specialist. Once a BED diagnosis is made, choices between types of therapy is dependent on clinician training and patient preference, though CBT does have the greatest body of evidence. If pharmacologic intervention is considered, lisdexamfetamine is FDA approved for BED. Future research focusing on the extent of dietary effects of BED on T2DM and further pharmacological research into BED may elucidate a uniform treatment algorithm.

\section{Funding}

AMC was supported, in part, by the National Institute of Nursing Research of the National Institutes of Health under Award Number K23NR017209.

\section{Disclosure}

Dr Thomas A Wadden reports personal fees from Novo Nordisk, Weight Watchers (WW), outside the submitted work. Dr Ariana M Chao reports grants, personal fees from Shire Pharmaceuticals, WW International., Inc., outside the submitted work. The authors report no other conflicts of interest in this work.

\section{References}

1. Centers for Disease Control. National Diabetes Statistics Report, 2017 Estimates of Diabetes and Its Burden in the United States Background.; 2017.

2. Wielgosz A, Dai S, Walsh P, McCrea-Logie J, Celebican E. Comorbid conditions in canadians hospitalized because of diabetes. Can J Diabetes. 2018;42(1):106-111. doi:10.1016/j.jcjd.2017.03.004 
3. Cryer MJ, Horani T, DiPette DJ. Diabetes and hypertension: a comparative review of current guidelines. J Clin Hypertens (Greenwich). 2016;18(2):95-100. doi:10.1111/jch.12638

4. Nowakowska M, Zghebi SS, Ashcroft DM, et al. The comorbidity burden of type 2 diabetes mellitus: patterns, clusters and predictions from a large English primary care cohort. BMC Med. 2019;17:1. doi:10.1186/s12916-019-1373-y

5. Bralić Lang V, Bergman Marković B. Prevalence of comorbidity in primary care patients with type 2 diabetes and its association with elevated HbA1c: a cross-sectional study in Croatia. Scand J Prim Health Care. 2016;34(1):66-72. doi:10.3109/02813432.2015.1132886

6. Herpertz S, Albus C, Lichtblau K, Köhle K, Mann K, Senf W. Relationship of weight and eating disorders in type 2 diabetic patients: a multicenter study. Int J Eat Disord. 2000;28(1):68-77. doi:10.1002/(SICI)1098-108X(200007)28:1<68::AID-EAT8>3.0. CO;2-R.

7. Petroni ML, Barbanti FA, Bonadonna R, et al. Dysfunctional eating in type 2 diabetes mellitus: a multicenter Italian study of socio-demographic and clinical associations. Nutr Metab Cardiovasc Dis. 2019;29(9):983-990. doi:10.1016/j.numecd.2019.06.006

8. Papelbaum M, Appolinário JC, de Moreira RO, Ellinger VCM, Kupfer R, Coutinho WF. Prevalence of eating disorders and psychiatric comorbidity in a clinical sample of type 2 diabetes mellitus patients. Rev Bras Psiquiatr. 2005;27(2):135-138.

9. Claudino AM, Pike KM, Hay P, et al. The classification of feeding and eating disorders in the ICD-11: results of a field study comparing proposed ICD-11 guidelines with existing ICD-10 guidelines. BMC Med. 2019;17(1):93. doi:10.1186/s12916-019-1327-4

10. Kessler RC, Berglund PA, Chiu WT, et al. The prevalence and correlates of binge eating disorder in the World Health Organization world mental health surveys. Biol Psychiatry. 2013;73(9):904-914. doi:10.1016/j.biopsych.2012.11.020

11. Galmiche M, Déchelotte P, Lambert G, Tavolacci MP. Prevalence of eating disorders over the 2000-2018 period: a systematic literature review. Am J Clin Nutr. 2019;109(5):1402-1413. doi:10.1093/ ajen/nqy342

12. Kolar DR, Rodriguez DLM, Chams MM, Hoek HW. Epidemiology of eating disorders in Latin America: a systematic review and meta-analysis. Curr Opin Psychiatry. 2016;29(6):363-371. doi:10.1097/YCO.0000000000000279

13. Hudson JI, Lalonde JK, Coit CE, et al. Longitudinal study of the diagnosis of components of the metabolic syndrome in individuals with binge-eating disorder. Am J Clin Nutr. 2010;91(6):1568-1573. doi:10.3945/ajen.2010.29203

14. Olguin P, Fuentes M, Gabler G, Guerdjikova AI, Keck PE, McElroy SL. Medical comorbidity of binge eating disorder. Eat Weight Disord - Stud Anorexia, Bulim Obes. 2017;22(1):13-26. doi:10.1007/s40519-016-0313-5

15. Abraham TM, Massaro JM, Hoffmann U, Yanovski JA, Fox CS. Metabolic characterization of adults with binge eating in the general population: the framingham heart study. Obesity. 2014;22 (11):2441-2449. doi:10.1002/oby.20867

16. Javaras KN, Pope HG, Lalonde JK, et al. Co-occurrence of binge eating disorder with psychiatric and medical disorders. $J$ Clin Psychiatry. 2008;69(2):266-273. doi:10.4088/jcp.v69n0213

17. Ágh T, Kovács G, Pawaskar M, Supina D, Inotai A, Vokó Z. Epidemiology, health-related quality of life and economic burden of binge eating disorder: a systematic literature review. Eat Weight Disord. 2015;20(1):1-12. doi:10.1007/s40519-014-0173-9

18. Meneghini LF, Spadola J, Florez H. Prevalence and associations of binge eating disorder in a multiethnic population with type 2 diabetes. Diabetes Care. 2006;29(12):2760. doi:10.2337/dc06-1364

19. Herpertz S, Wagener R, Albus C, et al. Diabetes mellitus and eating disorders: a multicenter study on the comorbidity of the two diseases. J Psychosom Res. 1998;44(3-4):503-515. doi:10.1016/ s0022-3999(97)00274-2
20. Wing RR, Marcus MD, LH E, EH B, Burton LR. Binge eating in obese patients with type II diabetes. Int J Eat Disord. 1989;8 (6):671-679. doi:10.1002/1098-108X(198911)8:6<671::AIDEAT2260080608 $>3.0 . \mathrm{CO} ; 2-5$

21. Mannucci E, Tesi F, Ricca V, et al. Eating behavior in obese patients with and without type 2 diabetes mellitus. Int $J$ Obes. 2002;26(6):848-853. doi:10.1038/sj.ijo.0801976

22. Kenardy J, Mensch M, Bowen K, Pearson S-A. A comparison of eating behaviors in newly diagnosed NIDDM patients and case-matched control subjects. Diabetes Care. 1994;17 (10):1197-1199. doi:10.2337/diacare.17.10.1197

23. Allison KC, Crow SJ, Reeves RR, et al. Binge eating disorder and night eating syndrome in adults with Type 2 diabetes*. Obesity. 2007;15(5):1287-1293. doi:10.1038/oby.2007.150

24.. Crow S, Kendall D, Praus B, Thuras P. Binge eating and other psychopathology in patients with type II diabetes mellitus. Int $J$ Eat Disord. 2001;30(2):222-226. doi:10.1002/eat.1077.

25. Introduction - Management and Outcomes of Binge-Eating Disorder - NCBI Bookshelf. Available from: https://www.ncbi. nlm.nih.gov/books/NBK338301/. Accessed February 24, 2020.

26. Cossrow N, Pawaskar M, Witt EA, et al. Estimating the prevalence of binge eating disorder in a community sample from the United States: comparing DSM-IV-TR and DSM-5 criteria. $J$ Clin Psychiatry. 2016;77(8):e968-e974. doi:10.4088/JCP.15m10059

27. Nieto-Martínez R, González-Rivas JP, Medina-Inojosa JR, Florez H. Are eating disorders risk factors for Type 2 diabetes? a systematic review and meta-analysis. Curr Diab Rep. 2017;17 (12):138. doi:10.1007/s11892-017-0949-1

28. Raevuori A, Suokas J, Haukka J, et al. Highly increased risk of type 2 diabetes in patients with binge eating disorder and bulimia nervosa. Int J Eat Disord. 2015;48(6):555-562. doi:10.1002/eat.22334

29. Herpertz S, Albus C, Wagener R, et al. Comorbidity of diabetes and eating disorders: does diabetes control reflect disturbed eating behavior? Diabetes Care. 1998;21(7):1110-1116. doi:10.2337/ diacare.21.7.1110

30. Yanovski SZ, Leet M, Yanovski JA, et al. Food selection and intake of obese women with binge-eating disorder. Am J Clin Nutr. 1992;56(6):975-980. doi:10.1093/ajcn/56.6.975

31. Siega-Riz AM, Haugen M, Meltzer HM, et al. Nutrient and food group intakes of women with and without bulimia nervosa and binge eating disorder during pregnancy. Am J Clin Nutr. 2008;87 (5):1346-1355. doi:10.1093/ajen/87.5.1346

32. Herbozo S, Flynn PM, Stevens SD, Betancourt H. Dietary adherence, glycemic control, and psychological factors associated with binge eating among indigenous and non-indigenous chileans with Type 2 diabetes. Int $J$ Behav Med. 2015;22(6):792-798. doi:10.1007/s12529-015-9478-y

33. Lourenço $\mathrm{BH}$, Arthur $\mathrm{T}$, Rodrigues $\mathrm{MDB}$, et al. Binge eating symptoms, diet composition and metabolic characteristics of obese children and adolescents. Appetite. 2008;50(2-3):223-230. doi:10.1016/j.appet.2007.07.004

34. Cooke EA, Guss JL, Kissileff HR, Devlin MJ, Walsh BT. Patterns of food selection during binges in women with binge eating disorder. Int J Eat Disord. 1997;22(2):187-193. doi:10.1002/(sici) 1098-108x(199709)22:2<187::aid-eat11>3.0.co;2-z

35. Raymond NC, Bartholome LT, Lee SS, Peterson RE, Raatz SK. A comparison of energy intake and food selection during laboratory binge eating episodes in obese women with and without a binge eating disorder diagnosis. Int $J$ Eat Disord. 2007;40(1):67-71. doi: $10.1002 /$ eat.20312

36. Allison S, Timmerman GM. Anatomy of a binge: food environment and characteristics of nonpurge binge episodes. Eat Behav. 2007;8 (1):31-38. doi:10.1016/j.eatbeh.2005.01.004

37. Goodman EL, Breithaupt L, Watson HJ, et al. Sweet taste preference in binge-eating disorder: A preliminary investigation. Eat Behav. 2018;28:8-15. doi:10.1016/j.eatbeh.2017.11.005 
38. Parry S, Woods R, Hodson L, Hulston C. A single day of excessive dietary fat intake reduces whole-body insulin sensitivity: the metabolic consequence of binge eating. Nutrients. 2017;9(8):818. doi:10.3390/nu9080818

39. Kenardy J, Mensch M, Bowen K, Green B, Walton J, Dalton M. Disordered eating behaviours in women with Type 2 diabetes mellitus. Eat Behav. 2001;2(2):183-192. doi:10.1016/S14710153(01)00028-9.

40. Sattar N, Rawshani A, Franzén S, et al. Age at diagnosis of Type 2 diabetes mellitus and associations with cardiovascular and mortality risks. Circulation. 2019;139(19):2228-2237. doi:10.1161/ CIRCULATIONAHA.118.037885

41. Abbott S, Dindol N, Tahrani AA, Piya MK. Binge eating disorder and night eating syndrome in adults with type 2 diabetes: a systematic review. J Eat Disord. 2018;6(1):36. doi:10.1186/ s40337-018-0223-1

42. Çelik S, Kayar Y, Önem Akçakaya R, et al. Correlation of binge eating disorder with level of depression and glycemic control in type 2 diabetes mellitus patients. Gen Hosp Psychiatry. 2015;37 (2):116-119. doi:10.1016/j.genhosppsych.2014.11.012

43. Papelbaum M, de Oliveira Moreira R, Coutinho WF, et al. Does binge-eating matter for glycemic control in type 2 diabetes patients? J Eat Disord. 2019;7(1):30. doi:10.1186/s40337-019-0260-4

44. Nagata JM, Garber AK, Tabler J, Murray SB, Vittinghoff E, Bibbins-Domingo K. Disordered eating behaviors and cardiometabolic risk among young adults with overweight or obesity. Int J Eat Disord. 2018;51(8):931-941. doi:10.1002/eat.22927

45. Gorin AA, Niemeier HM, Hogan P, et al. Binge eating and weight loss outcomes in overweight and obese individuals with Type 2 diabetes. Arch Gen Psychiatry. 2008;65(12):1447. doi:10.1001/ archpsyc.65.12.1447

46. Caroleo M, Carbone EA, Greco M, et al. Brain-behavior-immune interaction: serum cytokines and growth factors in patients with eating disorders at extremes of the body mass index (BMI) spectrum. Nutrients. 2019;11:9. doi:10.3390/nu11091995

47. Chao AM, Rajagopalan AV, Tronieri JS, Walsh O, Wadden TA. Identification of binge eating disorder criteria: results of a national survey of healthcare providers. J Nurs Scholarsh an off Publ Sigma Theta Tau Int Honor Soc Nurs. 2019;51(4):399-407. doi:10.1111/ jnu. 12468

48. Supina D, Herman BK, Frye CB, Shillington AC. Knowledge of binge eating disorder: a cross-sectional survey of physicians in the United States. Postgrad Med. 2016;128(3):311-316. doi:10.1080/ 00325481.2016 .1157441

49. Crow SJ, Peterson CB, Levine AS, Thuras P, Mitchell JE. A survey of binge eating and obesity treatment practices among primary care providers. Int J Eat Disord. 2004;35(3):348-353. doi:10.1002/ eat. 10266

50. Hay P, Ghabrial B, Mannan H, et al. General practitioner and mental healthcare use in a community sample of people with diagnostic threshold symptoms of bulimia nervosa, binge-eating disorder, and other eating disorders. Int J Eat Disord. 2019. doi:10.1002/eat.23174

51. Herman BK, Safikhani S, Hengerer D, et al. The patient experience with DSM-5-defined binge eating disorder: characteristics, barriers to treatment, and implications for primary care physicians. Postgrad Med. 2014;126(5):52-63. doi:10.3810/pgm.2014.09.2800

52. Kornstein SG, Kunovac JL, Herman BK, Culpepper L. Recognizing binge-eating disorder in the clinical setting: A review of the literature. Prim Care Companion J Clin Psychiatry. 2016;18:3. doi:10.4088/ PCC.15r01905

53. Becker AE, Hadley Arrindell A, Perloe A, Fay K, Striegel-Moore RH. A qualitative study of perceived social barriers to care for eating disorders: perspectives from ethnically diverse health care consumers. Int J Eat Disord. 2010;43(7):633-647. doi:10.1002/ eat. 20755
54. Blomquist KK, Roberto CA, Barnes RD, White MA, Masheb RM, Grilo CM. Development and validation of the eating loss of control scale. Psychol Assess. 2014;26(1):77-89. doi:10.1037/a0034729

55. Roberto CA, Galbraith K, Lydecker JA, et al. Preferred descriptions for loss of control while eating and weight among patients with binge eating disorder. Psychiatry Res. 2016;246:548-553. doi:10.1016/j.psychres.2016.09.045

56. Hart LM, Granillo MT, Jorm AF, Paxton SJ. Unmet need for treatment in the eating disorders: a systematic review of eating disorder specific treatment seeking among community cases. Clin Psychol Rev. 2011;31(5):727-735. doi:10.1016/j.cpr.2011.03.004

57. Aoun A, Azzam J, El Jabbour F, et al. Validation de la version en langue arabe du questionnaire SCOFF pour le dépistage des troubles alimentaires. East Mediterr Heal J. 2015;21(5):326-331. doi:10.26719/2015.21.5.326

58. Zeidan RK, Haddad C, Hallit R, et al. Validation of the Arabic version of the binge eating scale and correlates of binge eating disorder among a sample of the Lebanese population. J Eat Disord. 2019;7(1):1. doi:10.1186/s40337-019-0270-2

59. Leung SF, Lee KL, Lee SM, et al. Psychometric properties of the SCOFF questionnaire (Chinese version) for screening eating disorders in Hong Kong secondary school students: a cross-sectional study. Int J Nurs Stud. 2009;46(2):239-247. doi:10.1016/j. ijnurstu.2008.09.004

60. Tong J, Shi J, Wang J, et al. Validity and reliability of the Chinese language version of the eating disorder examination (CEDE) in mainland China: implications for the identity and nosology of the eating disorders. Int J Eat Disord. 2011;44(1):76-80. doi:10.1002/ eat. 20742

61. He J, Sun S, Fan X. Validation of the 12-item Short Form of the Eating Disorder Examination Questionnaire in the Chinese context: confirmatory factor analysis and Rasch analysis. Eat Weight Disord. 2020. doi:10.1007/s40519-019-00840-3

62. Becker AE, Thomas JJ, Bainivualiku A, et al. Validity and reliability of a Fijian translation and adaptation of the eating disorder examination questionnaire. Int J Eat Disord. 2010;43(2):171-178. doi:10.1002/eat.20675

63. Isomaa R, Lukkarila IL, Ollila T, et al. Development and preliminary validation of a Finnish version of the Eating Disorder Examination Questionnaire (EDE-Q). Nord J Psychiatry. 2016;70 (7):542-546. doi:10.1080/08039488.2016.1179340

64. Lähteenmäki S, Aalto-Setälä T, Suokas JT, et al. Validation of the Finnish version of the SCOFF questionnaire among young adults aged 20 to 35 years. BMC Psychiatry. 2009;9(1):5. doi:10.1186/ 1471-244X-9-5

65. Garcia FD, Grigioni S, Chelali S, Meyrignac G, Thibaut F, Dechelotte P. Validation of the French version of SCOFF questionnaire for screening of eating disorders among adults. World J Biol Psychiatry. 2010;11 (7):888-893. doi:10.3109/15622975.2010.483251

66. Brunault P, Gaillard P, Ballon N, et al. Validation de la version française de la Binge Eating Scale: étude de sa structure factorielle, de sa consistance interne et de sa validité de construit en population clinique et non clinique. Encephale. 2016;42(5):426-433. doi:10.1016/j.encep.2016.02.009

67. Richter F, Strauß B, Berger U. Brief instruments in German for the assessment of disordered eating. PPmP Psychother Psychosom Medizinische Psychol. 2018;68(3-4):99-108. doi:10.1055/s-0043106433

68. Pliatskidou S, Samakouri M, Kalamara E, et al. [Reliability of the Greek version of the eating disorder examination questionnaire (EDE-Q) in a sample of adolescent students]. Psychiatrike. 23 (4):295-303. Modern Greek.

69. Calugi S, Milanese C, Sartirana M, et al. The Eating Disorder Examination Questionnaire: reliability and validity of the Italian version. Eat Weight Disord. 2017;22(3):509-514. doi:10.1007/ s40519-016-0276-6 
70. Baceviciene M, Balciuniene V, Jankauskiene R. Validation of the Lithuanian version of the Eating Disorder Examination Questionnaire 6.0 in a student sample. Brain Behav. 2020;e01555. doi:10.1002/brb3.1555

71. Robert SA, Rohana AG, Suehazlyn Z, Maniam T, Azhar SS, Azmi KN. The validation of the malay version of binge eating scale: A comparison with the structured clinical interview for the DSM-IV. J Eat Disord. 2013;1(1):28. doi:10.1186/2050-2974-1-28

72. Ferrari Borges MB, Morgan CM, Claudino AM, Da Silveira DX. Validation of the Portuguese version of the Questionnaire on Eating and Weight Patterns - Revised (QEWP-R) for the screening of binge eating disorder. Rev Bras Psiquiatr. 2005;27(4):319-322. doi:10.1590/s1516-44462005000400012

73. Garcia-Campayo J, Sanz-Carrillo C, Ibañez JA, Lou S, Solano V, Alda M. Validation of the Spanish version of the SCOFF questionnaire for the screening of eating disorders in primary care. J Psychosom Res. 2005;59(2):51-55. doi:10.1016/j.jpsychores.2004.06.005

74. Robles ME, Oberst ÚE, Sánchez-Planell L, Chamarro A. Adaptación transcultural al castellano de la Eating Disorder Examination. Med Clin (Barc). 2006;127(19):734-735. doi:10.1157/13095526

75. Grilo CM, Crosby RD, White MA. Spanish-language Eating Disorder Examination interview: factor structure in Latino/as. Eat Behav. 2012;13(4):410-413. doi:10.1016/j.eatbeh.2012.07.006

76. Peláez-Fernández MA, Labrador FJ, Raich RM. Validation of Eating Disorder Examination Questionnaire (EDE-Q) -Spanish version- for screening eating disorders. Span J Psychol. 2012;15 (2):817-824. doi:10.5209/rev_sjop.2012.v15.n2.38893

77. Yucel B, Polat A, Ikiz T, Dusgor BP, Yavuz AE, Berk OS. The Turkish version of the eating disorder examination questionnaire: reliability and validity in adolescents. Eur Eat Disord Rev. 2011;19 (6):509-511. doi:10.1002/erv.1104

78. Elbir M, Alp Topbaş Ö, Bayad S, et al. Adaptation and reliability of the structured clinical interview for DSM-5-disorders - clinician version (SCID-5/CV) to the Turkish language. Turk Psikiyatr Derg. 2019;30:1. doi:10.5080/u23431

79. Morgan JF, Reid F, Lacey JH. The SCOFF questionnaire: assessment of a new screening tool for eating disorders. BMJ. 1999;319 (7223):1467-1468. doi:10.1136/bmj.319.7223.1467

80. Solmi F, Hatch SL, Hotopf M, Treasure J, Micali N. Validation of the SCOFF questionnaire for eating disorders in a multiethnic general population sample. Int $J$ Eat Disord. 2015;48(3):312-316. doi:10.1002/eat.22373

81. Sanchez-Armass O, Raffaelli M, Andrade FCD, et al. Validation of the SCOFF questionnaire for screening of eating disorders among Mexican university students. Eat Weight Disord. 2017;22 (1):153-160. doi:10.1007/s40519-016-0259-7

82. Mond JM, Myers TC, Crosby RD, et al. Screening for eating disorders in primary care: EDE-Q versus SCOFF. Behav Res Ther. 2008;46(5):612-622. doi:10.1016/j.brat.2008.02.003

83. Cotton MA, Ball C, Robinson P. Four simple questions can help screen for eating disorders. $J$ Gen Intern Med. 2003;18(1):53-56. doi:10.1046/j.1525-1497.2003.20374.x

84. Maguen S, Hebenstreit C, Li Y, et al. Screen for disordered eating: improving the accuracy of eating disorder screening in primary care. Gen Hosp Psychiatry. 2018;50:20-25. doi:10.1016/j.genhosppsych. 2017.09.004

85. Gormally J, Black S, Daston S, Rardin D. The assessment of binge eating severity among obese persons. Addict Behav. 1982;7 (1):47-55. doi:10.1016/0306-4603(82)90024-7

86. Ricca V, Mannucci E, Moretti S, et al. Screening for binge eating disorder in obese outpatients. Compr Psychiatry. 2000;41 (2):111-115. doi:10.1016/s0010-440x(00)90143-3

87. Chamay-Weber C, Combescure C, Lanza L, Carrard I, Haller DM. Screening obese adolescents for binge eating disorder in primary care: the adolescent binge eating scale. J Pediatr. 2017;185(68-72. e1):68-72.e1. doi:10.1016/j.jpeds.2017.02.038
88. Grupski AE, Hood MM, Hall BJ, Azarbad L, Fitzpatrick SL, Corsica JA. Examining the Binge Eating Scale in screening for binge eating disorder in bariatric surgery candidates. Obes Surg. 2013;23(1):1-6. doi:10.1007/s11695-011-0537-4

89. Hood MM, Grupski AE, Hall BJ, Ivan I, Corsica J. Factor structure and predictive utility of the Binge Eating Scale in bariatric surgery candidates. Surg Obes Relat Dis. 2013;9(6):942-948. doi:10.1016/j. soard.2012.06.013

90. Marek RJ, Tarescavage AM, Ben-Porath YS, Ashton K, Heinberg LJ. Replication and evaluation of a proposed two-factor Binge Eating Scale (BES) structure in a sample of bariatric surgery candidates. Surg Obes Relat Dis. 11(3):659-665. doi:10.1016/j. soard.2014.09.015

91. Duarte C, Pinto-Gouveia J, Ferreira C. Expanding binge eating assessment: validity and screening value of the Binge Eating Scale in women from the general population. Eat Behav. 2015;18:41-47. doi:10.1016/j.eatbeh.2015.03.007

92. Cooper Z, Fairburn C. The eating disorder examination: a semistructured interview for the assessment of the specific psychopathology of eating disorders. Int $J$ Eat Disord. 1987;6(1):1-8. doi:10.1002/1098-108X(198701)6:1<1::AID-EAT2260060102>3. $0 . \mathrm{CO} ; 2-9$

93. Fairburn CG, Beglin SJ. Assessment of eating disorders: interview or self-report questionnaire? Int J Eat Disord. 1994;16(4):363-370. doi:10.1002/1098-108X(199412)16:4<363::AIDEAT2260160405>3.0.CO;2-\#

94. Fairburn C, Cooper Z, O'Connor M. Eating Disorder Examination (Edition 17.0D; April, 2014). 2014.

95. Ø R, Reas DL, Stedal K. Eating Disorder Examination Questionnaire (EDE-Q) in Norwegian Adults: discrimination between female controls and eating disorder patients. Eur Eat Disord Rev. 2015;23 (5):408-412. doi:10.1002/erv.2372

96. Aardoom JJ, Dingemans AE, Slof Op't Landt MCT, Van Furth EF. Norms and discriminative validity of the Eating Disorder Examination Questionnaire (EDE-Q). Eat Behav. 2012;13(4):305-309. doi:10. 1016/j.eatbeh.2012.09.002

97. Reas DL, Grilo CM, Masheb RM. Reliability of the Eating Disorder Examination-Questionnaire in patients with binge eating disorder. Behav Res Ther. 2006;44(1):43-51. doi:10.1016/j.brat.2005.01.004

98. Gideon N, Hawkes N, Mond J, Saunders R, Tchanturia K, Serpell L. Development and psychometric validation of the EDE-QS, a 12 item short form of the eating disorder examination questionnaire (EDE-Q). Takei N, ed. PLoS One. 2016;11(5):e0152744. doi:10.1371/journal. pone. 0152744

99. Kliem S, Mößle T, Zenger M, Strauß B, Brähler E, Hilbert A. The eating disorder examination-questionnaire 8: A brief measure of eating disorder psychopathology (EDE-Q8). Int $J$ Eat Disord. 2016;49(6):613-616. doi:10.1002/eat.22487

100. Lydecker JA, White MA, Grilo CM. Black patients with binge-eating disorder: comparison of different assessment methods. Psychol Assess. 2016;28(10):1319-1324. doi:10.1037/pas0000246

101. Barnes RD, Masheb RM, White MA, Grilo CM. Comparison of methods for identifying and assessing obese patients with binge eating disorder in primary care settings. Int J Eat Disord. 2011;44 (2):157-163. doi:10.1002/eat.20802

102. Grilo CM, Masheb RM, Wilson GT. Different methods for assessing the features of eating disorders in patients with binge eating disorder: a replication. Obes Res. 2001;9(7):418-422. doi:10.1038/oby.2001.55

103. Grilo CM, Masheb RM, Wilson GT. A comparison of different methods for assessing the features of eating disorders in patients with binge eating disorder. $J$ Consult Clin Psychol. 2001;69 (2):317-322. doi:10.1037//0022-006x.69.2.317

104. Goldfein JA, Devlin MJ, Kamenetz C. Eating disorder examination-questionnaire with and without instruction to assess binge eating in patients with binge eating disorder. Int J Eat Disord. 2005;37(2):107-111. doi:10.1002/eat.20075 
105. Spitzer RL, Devlin M, Walsh BT, et al. Binge eating disorder: A multisite field trial of the diagnostic criteria. Int $J$ Eat Disord 1992;11(3):191-203. doi:10.1002/1098-108X(199204)11:3<191:: AID-EAT2260110302>3.0.CO;2-S

106. Spitzer RL, Yanovski S, Wadden T, et al. Binge eating disorder: its further validation in a multisite study. Int J Eat Disord. 1993;13 (2):137-153. doi:10.1002/1098-108X(199303)13:2<137::AID-EAT 2260130202>3.0.CO;2-\#

107. Yanovski SZ, Marcus MD, Wadden TA, Walsh BT. The Questionnaire on Eating and Weight Patterns-5: an updated screening instrument for binge eating disorder. Int J Eat Disord. 2015;48 (3):259-261. doi:10.1002/eat.22372

108. Borges MBF, Morgan CM, Claudino AM, da Silveira DX. Validation of the Portuguese version of the Questionnaire on Eating and Weight Patterns-Revised (QEWP-R) for the screening of binge eating disorder. Rev Bras Psiquiatr. 2005;27(4):319-322. doi:10.1590//S1516-44462005000400012

109. Nangle DW, Johnson WG, Carr-Nangle RE, Engler LB. Binge eating disorder and the proposed DSM-IV criteria: psychometric analysis of the questionnaire of eating and weight patterns. Int $J$ Eat Disord. 1994;16(2):147-157. doi:10.1002/1098-108x(199409) 16:2<147::aid-eat2260160206 >3.0.co;2-p

110. Celio AA, Wilfley DE, Crow SJ, Mitchell J, Walsh BT. A comparison of the binge eating scale, questionnaire for eating and weight patterns-revised, and eating disorder examination questionnaire with instructions with the eating disorder examination in the assessment of binge eating disorder and its symptoms. Int $J$ Eat Disord. 2004;36(4):434-444. doi:10.1002/eat.20057

111. Gladis MM, Wadden TA, Foster GD, Vogt RA, Wingate BJ. A comparison of two approaches to the assessment of binge eating in obesity. Int J Eat Disord. 1998;23(1):17-26. doi:10.1002/(SICI) 1098-108X(199801)23:1<17::AID-EAT3>3.0.CO;2-4.

112. Wilfley DE, Schwartz MB, Spurrell EB, Fairburn CG. Using the eating disorder examination to identify the specific psychopathology of binge eating disorder. Int J Eat Disord. 2000;27(3):259-269. doi:10.1002/ (SICI)1098-108X(200004)27:3<259::AID-EAT2>3.0.CO;2-G

113. Cooper Z, Cooper PJ, Fairburn CG. The validity of the eating disorder examination and its subscales. Br J Psychiatry. 1989;154 (6):807-812. doi:10.1192/bjp.154.6.807

114. Guest T. Using the eating disorder examination in the assessment of bulimia and anorexia: issues of reliability and validity. Soc Work Health Care. 2000;31(4):71-83. doi:10.1300/J010v31n04_05

115. Grilo CM, Masheb RM, Lozano-Blanco C, Barry DT. Reliability of the Eating Disorder Examination in patients with binge eating disorder. Int J Eat Disord. 2004;35(1):80-85. doi:10.1002/eat.10238

116. Spitzer RL, Williams JBW, Gibbon M, First MB. The structured clinical interview for DSM-III-R (SCID): I: history, rationale, and description. Arch Gen Psychiatry. 1992;49(8):624-629. doi:10.1001/ archpsyc. 1992.01820080032005

117. APA. The Structured Clinical Interview for DSM- $5{ }^{\circledR}$. Available from: https://www.appi.org/products/structured-clinical-interviewfor-dsm-5-scid-5. Accessed November 21, 2019.

118. Shankman SA, Funkhouser CJ, Klein DN, Davila J, Lerner D, Hee D. Reliability and validity of severity dimensions of psychopathology assessed using the Structured Clinical Interview for DSM-5 (SCID). Int $J$ Methods Psychiatr Res. 2018;27:1. doi: $10.1002 / \mathrm{mpr} .1590$

119. Zimmerman M, Clark H, McGonigal P, Harris L, Holst CG, Martin J. Reliability and validity of the DSM-5 anxious distress specifier interview. Compr Psychiatry. 2017;76:11-17. doi:10.1016/ j.comppsych.2017.02.010

120. Zawadzki B, Popiel A, Cyniak-Cieciura M, Jakubowska B, Pragłowska E. Diagnoza pourazowego zaburzenia stresowego (PTSD) za pomoca ustrukturalizowanego wywiadu klinicznego SCID-I. Psychiatr Pol. 2015;49(1):159-169. doi:10.12740/PP/ 32214
121. Gerdner A, Kestenberg J, Edvinsson M. Validity of the Swedish SCID and ADDIS diagnostic interviews for substance use disorders: sensitivity and specificity compared with a LEAD golden standard. Nord J Psychiatry. 2015;69(1):48-56. doi:10.3109/ 08039488.2014.926987

122. Linardon J, Wade TD, De La Piedad Garcia X, Brennan L. The efficacy of cognitive-behavioral therapy for eating disorders: A systematic review and meta-analysis. $J$ Consult Clin Psychol. 2017;85(11):1080-1094. doi:10.1037/ccp0000245

123. Peat CM, Berkman ND, Lohr KN, et al. Comparative effectiveness of treatments for binge-eating disorder: systematic review and network meta-analysis. Eur Eat Disord Rev. 2017;25(5):317-328. doi:10.1002/erv. 2517

124. Dingemans AE, Bruna MJ, van Furth EF. Binge eating disorder: a review. Int J Obes Relat Metab Disord. 2002;26(3):299-307. doi:10.1038/sj.ijo.0801949

125. Agras WS. Cognitive behavior therapy for the eating disorders. Psychiatr Clin North Am. 2019;42(2):169-179. doi:10.1016/j. psc.2019.01.001

126. Palavras MA, Hay P, Dos Filho CAS, Claudino A. The efficacy of psychological therapies in reducing weight and binge eating in people with bulimia nervosa and binge eating disorder who are overweight or obese - a critical synthesis and meta-analyses. Nutrients. 2017;9(3):299. doi:10.3390/nu9030299

127. Loeb KL, Wilson GT, Gilbert JS, Labouvie E. Guided and unguided self-help for binge eating. Behav Res Ther. 2000;38 (3):259-272. doi:10.1016/s0005-7967(99)00041-8

128. Grilo CM, Masheb RM. A randomized controlled comparison of guided self-help cognitive behavioral therapy and behavioral weight loss for binge eating disorder. Behav Res Ther. 2005;43 (11):1509-1525. doi:10.1016/j.brat.2004.11.010

129. Fairburn CG. Overcoming Binge Eating: The Proven Program to Learn Why You Binge and How You Can Stop.

130. Lynch FL, Striegel-Moore RH, Dickerson JF, et al. Cost-effectiveness of guided self-help treatment for recurrent binge eating. $j$ consult clin psychol. 2010;78(3):322-333. doi:10.1037/a0018982

131. König HH, Bleibler F, Friederich HC, et al. Economic evaluation of cognitive behavioral therapy and Internet-based guided self-help for binge-eating disorder. Int J Eat Disord. 2018;51(2):155-164. doi:10.1002/eat.22822

132. Uchendu C, Blake H. Effectiveness of cognitive-behavioural therapy on glycaemic control and psychological outcomes in adults with diabetes mellitus: a systematic review and meta-analysis of randomized controlled trials. Diabet Med. 2017;34(3):328-339. doi:10.1111/dme.13195

133. Ghaderi A, Odeberg J, Gustafsson S, et al. Psychological, pharmacological, and combined treatments for binge eating disorder: a systematic review and metaanalysis. PeerJ. 2018;2018:6. doi:10.7717/peerj.5113

134. Grilo C. (Carlos M., Mitchell JE (James E)). The Treatment of Eating Disorders: A Clinical Handbook. Guilford Press; 2010.

135. Crow SJ. Group interpersonal psychotherapy may be as effective as group cognitive behavioural therapy for overweight people with binge eating disorder: commentary. Evid Based Ment Health. 2003;6(2):56. doi:10.1136/ebmh.6.2.56

136. Wilfley DE, Robinson Welch R, Stein RI, et al. A randomized comparison of group cognitive-behavioral therapy and group interpersonal psychotherapy for the treatment of overweight individuals with binge-eating disorder. Arch Gen Psychiatry. 2002;59 (8):713-721. doi:10.1001/archpsyc.59.8.713

137. Bosmans JE, Van Schaik DJF, Heymans MW, Van Marwijk HWJ, Van Hout HPJ, De Bruijne MC. Cost-effectiveness of interpersonal psychotherapy for elderly primary care patients with major depression. Int J Technol Assess Health Care. 2007;23(4):480-487. doi:10.1017/ S0266462307070572

138. Striegel-Moorel RH, Franko DL. Epidemiology of binge eating disorder. Int J Eat Disord. 2003;34(SUPPL). doi:10.1002/eat.10202 
139. Norris SL, Zhang X, Avenell A, et al. Long-term effectiveness of lifestyle and behavioral weight loss interventions in adults with type 2 diabetes: A meta-analysis. Am J Med. 2004;117(10):762-774. doi:10.1016/j.amjmed.2004.05.024

140. Wing RR, Bolin P, Brancati FL, et al. Cardiovascular effects of intensive lifestyle intervention in type 2 diabetes. $N$ Engl J Med. 2013;369(2):145-154. doi:10.1056/NEJMoa1212914

141. McAndrew LM, Napolitano MA, Pogach LM, et al. The impact of self-monitoring of blood glucose on a behavioral weight loss intervention for patients with type 2 diabetes. Diabetes Educ. 2013;39 (3):397-405. doi:10.1177/0145721712449434

142. Johansen MY, Macdonald CS, Hansen KB, et al. Effect of an intensive lifestyle intervention on glycemic control in patients with type 2 diabetes: a randomized clinical trial. JAMA - J Am Med Assoc. 2017;318(7):637-646. doi:10.1001/jama.2017.10169

143. Sbroma Tomaro E, Pippi R, Reginato E, et al. Intensive lifestyle intervention is particularly advantageous in poorly controlled type 2 diabetes. Nutr Metab Cardiovasc Dis. 2017;27(8):688-694. doi:10.1016/j.numecd.2017.06.009

144. Gamiochipi M, Cruz M, Kumate J, Wacher NH. Effect of an intensive metabolic control lifestyle intervention in type-2 diabetes patients. Patient Educ Couns. 2016;99(7):1184-1189. doi:10.1016/ j.pec.2016.01.017

145. Chao AM, Wadden TA, Gorin AA, et al. Binge eating and weight loss outcomes in individuals with Type 2 diabetes: 4-year results from the look AHEAD study. Obesity. 2017;25(11):1830-1837. doi:10.1002/oby.21975

146. Masheb RM, Lutes LD, Myra Kim H, et al. High-frequency binge eating predicts weight gain among veterans receiving behavioral weight loss treatments. Obesity. 2015;23(1):54-61. doi:10.1002/oby.20931

147. Gladis MM, Wadden TA, Vogt R, Foster G, Kuehnel RH, Bartlett SJ. Behavioral treatment of obese binge eaters: do they need different care? J Psychosom Res. 1998;44(3-4):375-384. doi:10.1016/s0022-3999(97)00262-6

148. Delinsky SS, Latner JD, Wilson GT. Binge eating and weight loss in a self-help behavior modification program. Obesity. 2006;14 (7):1244-1249. doi:10.1038/oby.2006.141

149. Pi-Sunyer $X$. The look AHEAD trial: a review and discussion of its outcomes. Current Nutrition Reports. 2014;3(4):387-391. doi:10.1007/s13668-014-0099-x

150. Munsch S, Biedert E, Meyer A, et al. A randomized comparison of cognitive behavioral therapy and behavioral weight loss treatment for overweight individuals with binge eating disorder. Int $J$ Eat Disord. 2007;40(2):102-113. doi:10.1002/eat.20350

151. Wilson GT, Wilfley DE, Agras WS, Bryson SW. Psychological treatments of binge eating disorder. Arch Gen Psychiatry. 2010;67 (1):94-101. doi:10.1001/archgenpsychiatry.2009.170

152. Pattinson AL, Nassar N, da Luz FQ, Hay P, Touyz S, Sainsbury A. The real happy study: protocol for a prospective assessment of the real-world effectiveness of the HAPIFED program - a healthy approach to weight management and food in eating disorders. Behav Sci (Basel). 2019;9:7. doi:10.3390/bs9070072

153. Palavras MA, Hay $\mathrm{P}$, Touyz $\mathrm{S}$, et al. Comparing cognitive behavioural therapy for eating disorders integrated with behavioural weight loss therapy to cognitive behavioural therapy-enhanced alone in overweight or obese people with bulimia nervosa or binge eating disorder: study protocol for a randomised controlled trial. Trials. 2015;16:1. doi:10.1186/s13063-015-1079-1

154. da Luz FQ, Swinbourne J, Sainsbury A, et al. HAPIFED: a healthy approach to weight management and food in eating disorders: a case series and manual development. J Eat Disord. 2017;5(1):1. doi:10.1186/s40337-017-0162-2

155. Appolinario JC, Nardi AE, McElroy SL. Investigational drugs for the treatment of binge eating disorder (BED): an update. Expert Opin Investig Drugs. 2019;28(12):1081-1094. doi:10.1080/13543784. 2019.1692813
156. McElroy SL. Pharmacologic treatments for binge-eating disorder. J Clin Psychiatry. 2017;78(Suppl 1):14-19. doi:10.4088/JCP. sh16003su1c.03.

157. McElroy SL, Hudson JI, Mitchell JE, et al. Efficacy and safety of lisdexamfetamine for treatment of adults with moderate to severe binge-eating disorder: a randomized clinical trial. JAMA Psychiatry. 2015;72(3):235-246. doi:10.1001/jamapsychiatry.2014.2162

158. Hudson JI, McElroy SL, Ferreira-Cornwell MC, Radewonuk J, Gasior M. Efficacy of lisdexamfetamine in adults with moderate to severe binge-eating disorder: a randomized clinical trial. JAMA Psychiatry. 2017;74(9):903-910. doi:10.1001/jamapsychiatry.2017. 1889

159. Apovian CM. Naltrexone/bupropion for the treatment of obesity and obesity with Type 2 diabetes. Future Cardiology. 2016;12 (2):129-138. doi:10.2217/fca.15.79

160. White MA, Grilo CM. Bupropion for overweight women with binge-eating disorder: a randomized, double-blind, placebo-controlled trial. J Clin Psychiatry. 2013;74(4):400-406. doi:10.4088/JCP. $12 \mathrm{~m} 08071$

161. Arnold LM, McElroy SL, Hudson JI, Welge JA, Bennett AJ, Keck PE. A placebo-controlled, randomized trial of fluoxetine in the treatment of binge-eating disorder. J Clin Psychiatry. 2002;63 (11):1028-1033. doi:10.4088/jcp.v63n1113

162. Hudson JI, McElroy SL, Raymond NC, et al. Fluvoxamine in the treatment of binge-eating disorder: a multicenter placebo-controlled, double-blind trial. Am J Psychiatry. 1998;155 (12):1756-1762. doi:10.1176/ajp.155.12.1756

163. McElroy SL, Hudson JI, Malhotra S, Welge JA, Nelson EB, Keck PE. Citalopram in the treatment of binge-eating disorder: a placebo-controlled trial. J Clin Psychiatry. 2003;64(7):807-813. doi:10.4088/jcp.v64n0711

164. McElroy SL, et al. Placebo-controlled trial of sertraline in the treatment of binge eating disorder. Am J Psychiatry. 2000;157 (6):1004-1006. doi:10.1176/appi.ajp.157.6.1004

165. Brownley KA, Berkman ND, Sedway JA, Lohr KN, Bulik CM. Binge eating disorder treatment: a systematic review of randomized controlled trials. Int $J$ Eat Disord. 2007;40(4):337-348. doi:10.1002/eat.20370

166. Ricca V, Mannucci E, Mezzani B, et al. Fluoxetine and fluvoxamine combined with individual cognitive-behaviour therapy in binge eating disorder: a one-year follow-up study. Psychother Psychosom. 2001;70(6):298-306. doi:10.1159/000056270

167. Grilo CM, Masheb RM, Wilson GT. Efficacy of cognitive behavioral therapy and fluoxetine for the treatment of binge eating disorder: a randomized double-blind placebo-controlled comparison. Biol Psychiatry. 2005;57(3):301-309. doi:10.1016/j.biopsych.2004.11.002

168. Whitten JS. Liraglutide (Saxenda) for Weight Loss. Am Fam Physician. 2016;94(2):161-166.

169. Robert SA, Rohana AG, Shah SA, Chinna K, Wan Mohamud WN, Kamaruddin NA. Improvement in binge eating in non-diabetic obese individuals after 3 months of treatment with liraglutide a pilot study. Obes Res Clin Pract. 2015;9(3):301-304. doi:10. 1016/j.orcp.2015.03.005

170. McElroy SL, Hudson JI, Capece JA, Beyers K, Fisher AC, Rosenthal NR. Topiramate for the treatment of binge eating disorder associated with obesity: a placebo-controlled study. Biol Psychiatry. 2007;61(9):1039-1048. doi:10.1016/j.biopsych.2006.08.008

171. Peterson CB, Mitchell JE, Crow SJ, Crosby RD, Wonderlich SA. The efficacy of self-help group treatment and therapist-led group treatment for binge eating disorder. Am J Psychiatry. 2009;166 (12):1347-1354. doi:10.1176/appi.ajp.2009.09030345

172. McElroy SL, Hudson J, Ferreira-Cornwell MC, Radewonuk J, Whitaker T, Gasior M. Lisdexamfetamine Dimesylate for adults with moderate to severe binge eating disorder: results of two pivotal Phase 3 randomized controlled trials. Neuropsychopharmacology. 2016;41(5):1251-1260. doi:10.1038/npp.2015.275 


\section{Publish your work in this journal}

Diabetes, Metabolic Syndrome and Obesity: Targets and Therapy is an international, peer-reviewed open-access journal committed to the rapid publication of the latest laboratory and clinical findings in the fields of diabetes, metabolic syndrome and obesity research. Original research, review, case reports, hypothesis formation, expert opinion and commentaries are all considered for publication. The manuscript management system is completely online and includes a very quick and fair peer-review system, which is all easy to use. Visit http://www.dovepress.com/testimonials.php to read real quotes from published authors.

Submit your manuscript here: https://www.dovepress.com/diabetes-metabolic-syndrome-and-obesity-targets-and-therapy-journal 